\title{
Evaluation of Knowledge, Attitude and Practices towards Diabetes and Determinant Factors of Diabetic Knowledge among Diabetic Patients: A Study in South India
}

\author{
Asharani ${ }^{1, *}$, Anagha Sridhar $B^{2}$ \\ ${ }^{1}$ Department of Biochemistry, Adichunchanagiri Institute of Medical Sciences, Adichunchanagiri University, B G Nagara, Mandya, \\ Karnataka, India \\ ${ }^{2}$ Adichunchanagiri Institute of Medical Sciences, Adichunchanagiri University, B G Nagara, Mandya, Karnataka, India
}

Received February 9, 2021; Revised March 16, 2021; Accepted April 22, 2021

\section{Cite This Paper in the following Citation Styles}

(a): [1] Asharani N, Anagha Sridhar B , "Evaluation of Knowledge, Attitude and Practices towards Diabetes and Determinant Factors of Diabetic Knowledge among Diabetic Patients: A Study in South India," Advances in Diabetes and Metabolism, Vol. 9, No. 1, pp. 6- 12, 2021. DOI: 10.13189/adm.2021.090102.

(b): Asharani N, Anagha Sridhar B (2021). Evaluation of Knowledge, Attitude and Practices towards Diabetes and Determinant Factors of Diabetic Knowledge among Diabetic Patients: A Study in South India. Advances in Diabetes and Metabolism, 9(1), 6 - 12. DOI: 10.13189/adm.2021.090102.

Copyright $\mathrm{O} 2021$ by authors, all rights reserved. Authors agree that this article remains permanently open access under the terms of the Creative Commons Attribution License 4.0 International License

\begin{abstract}
Background: Diabetes Mellitus is a multifactorial metabolic disorder characterized by hyperglycaemia which on long standing results in microvascular and macrovascular complications. Knowledge, attitude and practices concerning diabetes mellitus are imperative to minimize the prevalence and morbidity associated with diabetes mellitus. Materials \& Methods: This cross-sectional study was conducted at a teaching rural hospital among 100 known diabetic patients visiting the hospital for regular check-up. The self-administered questionnaire collected the data to assess knowledge, attitude and practices towards diabetes and knowledge determinant factors. Participant's socio-demographic characteristics including gender, level of education and duration of diabetes was reported using descriptive statistics. Mean and SD was used to express the age, anthropometric measurements, glucose levels and knowledge score. The response of knowledge, attitude and practice questions was expressed as frequency and percentage. The logistic regression analysis was done to determine the association between gender, age group, educational status and duration of diabetes with knowledge score. The level of statistical significance was set at $p<0.05$. Results: Of the total 100participants, $52 \%$
\end{abstract}

were males and 135 were illiterate. $77 \%$ had good knowledge of diabetes symptoms, risk factors, complications, life style modifications and glucose monitoring. $77 \%, 88 \%$ and $76 \%$ had good knowledge, positive attitude and good practices respectively. The regression analysis showed increased odds of good knowledge among females [(1.552 (0.559 - 4.311)] and in subjects with diabetes of more than 5years $[1.090(0.278-$ 4.264)]. Further the analysis showed that the knowledge on diabetes was poor as participant's age advanced [OR: 0.281(0.065 - 1.217) \& OR: $0.199(0.046$ - 0.864)]. Additionally, there were increased odds of good knowledge in participants with increase in educational level. Conclusion: Majority of the participants had good knowledge, positive attitude and good practices, however there is still scope for improvement in the areas such as inclusion of regular exercise, periodic lipid profile analysis and eye examination.

Keywords Attitude, Diabetes Mellitus, Diabetes Knowledge Questionnaire, Knowledge, Practices 


\section{Introduction}

Globally, prevalence of diabetes among adults has drastically risen from $4.7 \%$ in 1980 to $8.5 \%$ in 2014[1]. World Health Organisation anticipates that diabetes will be the $7^{\text {th }}$ leading cause of death by 2030[2].This emphasizes the need to look at the factors which improve outcomes for patients with diabetes mellitus and in particular, the factors which contribute to improved glycemic control.

Knowledge, attitude and practices concerning diabetes mellitus are imperative to minimize the prevalence and morbidity associated with diabetes mellitus. Diabetes education is considered as an essential tool, as its management largely depends on knowledge, motivation and ability to practice self-care in daily activities [3].

Many studies report that diabetic patients having good knowledge and motivated to do self-care achieve better glycemic control. However, there is difference of opinion on effectiveness of method of health instruction and educational efforts undertaken [4-6].It is a well-liked assumption that good KAP would equate to adequate glycemic control in diabetes, but it may not be related to reality [7-8].

Further there is a paucity of evidence regarding impact of diabetic knowledge on glycemic control among diabetic patients in rural South India. In this regard the present study was designed to assess the level of knowledge, attitude and practices and also to determine the association of age, gender, educational level and duration of diabetes with diabetic knowledge among type 2 diabetic patients.

\section{Materials \& Methods}

This cross-sectional study was conducted at a teaching rural hospital after approval by the institutional ethics committee. 100 diabetic patients both male and female aged $>40$ years diagnosed diabetes as per the American Diabetes Association (ADA) criteria [9] visiting the hospital for regular check-up were enrolled in the study. Subjects who did not consent to participate in the project, type $1 \mathrm{DM}$, pregnant women or with intellectual impairment were excluded.

A pre-designed and validated KAP questionnaire was used as a tool. The questionnaire has been used in previous KAP studies among diabetics and has proven to be reliable $[3,7,10]$. A small pilot test was carried out in a sample group of 10 participants to assess the appropriateness and clarity of the questionnaire.

The questionnaire had a total of 25 questions (knowledge -14, attitude - 5, and practice - 6). Each correct response was given a score of 'one' and the wrong response a score of 'zero'. A score of 8 and above was considered as good knowledge. Similarly, for attitude and practices a score of $\geq 3$ were categorized as having positive attitude and good practices.

\section{Statistical Analysis}

Data was analysed using the SPSS, version 18. Participant's socio-demographic characteristics including gender, level of education and duration of diabetes was reported as frequency and percentage. Mean and SD were used to express the age, anthropometric measurements and glucose levels.

The response of knowledge, attitude and practice questions was expressed as frequency and percentage. The logistic regression analysis was done to determine the association between gender, age group, educational status and duration of diabetes with knowledge score. The level of statistical significance was set at $\mathrm{p}<0.05$.

\section{Results}

\subsection{Sociodemographic Profile of the Study Participants} (Table 1)

Of the 100 study participants, $52 \%$ were males and $48 \%$ were females. As for the variable of educational status of the participants, $38 \%$ were graduates followed by higher secondary $(26 \%)$, primary education $(23 \%)$ and the least was being illiterate (13\%). Further $85 \%$ of the subjects had diabetes duration of $<5$ years and $40 \%$ were above the age of 60 years. (Table 1 )

Table 1. Socio-demographic profile of the study participants

\begin{tabular}{|c|c|c|}
\hline Variables & Categories & Frequency / \% \\
\hline \multirow{2}{*}{ Sex } & Male & 52 \\
\hline & Female & 42 \\
\hline \multirow{3}{*}{ Age group } & $40-50$ & 30 \\
\hline & $51-60$ & 30 \\
\hline & 61 & 40 \\
\hline \multirow{4}{*}{ Educational status } & Illiterate & 13 \\
\hline & Primary education & 23 \\
\hline & Higher Secondary & 26 \\
\hline & Graduate & 38 \\
\hline \multirow{2}{*}{ Duration of diabetes } & $\leq 5$ years & 85 \\
\hline & $>5$ years & 15 \\
\hline
\end{tabular}

\subsection{Anthropometric Details of Study Participants (Table 2)}

There was no statistical difference between the mean BMI values of males and females. Even though the mean fasting plasma glucose value was high in females and postprandial plasma glucose was high among males, the difference was not statistically significant ( $p$ value $-0.23 \&$ 0.80 respectively) 
Table 2. Mean values of anthropometric measurements and plasma glucose of the participants

\begin{tabular}{|c|c|c|c|}
\hline Parameters & Male $(\mathbf{N = 5 2 )}$ & $\begin{array}{c}\text { Female } \\
(\mathbf{N = 4 8 )}\end{array}$ & P value \\
\hline Height $(\mathrm{cm})$ & $169 \pm 7$ & $160 \pm 7.66$ & $0.0001^{*}$ \\
\hline Weight $(\mathrm{Kg})$ & $66 \pm 12$ & $58 \pm 9.91$ & $0.0005^{*}$ \\
\hline $\begin{array}{c}\text { Waist } \\
\text { circumference } \\
(\mathrm{cm})\end{array}$ & $98 \pm 16$ & $95 \pm 19.46$ & 0.40 \\
\hline BMI $\left(\mathrm{Kg} / \mathrm{M}^{2}\right)$ & $23 \pm 4$ & $23 \pm 4.55$ & 1.00 \\
\hline FPG $(\mathrm{mg} / \mathrm{dL})$ & $156.52 \pm 44.01$ & $170 \pm 66.6$ & 0.23 \\
\hline PPPG (mg/dL) & $241.46 \pm 74.27$ & $237 \pm 89.87$ & 0.80 \\
\hline
\end{tabular}

BMI- Body Mass Index, FPG- Fasting Plasma Glucose, PPPG - Post Prandial Plasma Glucose. *-statistically significant

\subsection{Knowledge of Study Participants (Table 3 \& 4)}

More than 3/4 of the study population had given correct response to knowledge items like symptoms of diabetes $(76 \%)$, risk factors and complications $(72 \%)$, other organs involved if diabetes is not treated (77\%), accurate methods of monitoring diabetes by blood glucose estimation (77\%) and life style modifications like consuming balance diet and medication (987\%) and reducing weight, avoiding alcohol and smoking (85\%) (Table 3). Out of 100 participants, $77 \%$ had good knowledge towards diabetes. (Table 4)

Table 3. Correct responses to knowledge items on diabetes among the study participants

\begin{tabular}{|c|c|c|c|}
\hline Knowledge questions & $\begin{array}{l}\text { Male } n=52 \\
\quad N(\%)\end{array}$ & $\begin{array}{c}\text { Female } n=48 \\
\quad N(\%)\end{array}$ & $\begin{array}{c}\text { Overall } n=100 \\
\quad \mathrm{~N}(\%)\end{array}$ \\
\hline $\begin{array}{l}\text { Diabetes is a condition in which the body contains higher level of } \\
\text { blood sugar than normal }\end{array}$ & 41 & 37 & 78 \\
\hline $\begin{array}{l}\text { The major causes of diabetes are hereditary, obesity, and } \\
\text { unhealthy eating habits }\end{array}$ & 37 & 32 & 69 \\
\hline $\begin{array}{l}\text { The symptoms of diabetes are frequent urination, increased thirst, } \\
\text { and hunger }\end{array}$ & 38 & 38 & 76 \\
\hline $\begin{array}{l}\text { Diabetes, if not treated, will cause damage to other organs such as } \\
\text { heart, eyes, kidneys, and foot ulcers }\end{array}$ & 39 & 38 & 77 \\
\hline $\begin{array}{l}\text { The most accurate method of monitoring diabetes is checking } \\
\text { blood glucose levels }\end{array}$ & 39 & 38 & 77 \\
\hline $\begin{array}{l}\text { In a diabetic patient, high blood pressure can worsen the risk of } \\
\text { heart attack, stroke, kidney, and eye problems }\end{array}$ & 37 & 35 & 72 \\
\hline $\begin{array}{l}\text { A diabetic patient should measure his or her blood pressure } \\
\text { regularly }\end{array}$ & 41 & 43 & 84 \\
\hline $\begin{array}{l}\text { The lifestyle modification required for diabetic patients is weight } \\
\text { reduction, stopping alcohol consumption, and smoking }\end{array}$ & 45 & 40 & 85 \\
\hline A diabetic patient should have his or her eyes checked every year & 38 & 35 & 73 \\
\hline $\begin{array}{l}\text { The important factors that help in controlling blood sugar are } \\
\text { controlled and planned diet, and medication }\end{array}$ & 45 & 42 & 87 \\
\hline $\begin{array}{l}\text { Regular urine tests will help in knowing the amount of proteins in } \\
\text { your urine and functional status of kidneys }\end{array}$ & 42 & 32 & 74 \\
\hline A regular exercise regimen will help in blood glucose control & 41 & 37 & 78 \\
\hline $\begin{array}{l}\text { A well-balanced diet include carbohydrates, proteins, fruits, and } \\
\text { fibres }\end{array}$ & 45 & 40 & 85 \\
\hline Diabetes is a curable disease & 25 & 13 & 38 \\
\hline
\end{tabular}

Table 4. Level of Diabetic knowledge among the participants

\begin{tabular}{|cc|c|c|c|}
\hline & & Male N (\%) & Female N (\%) & Overall N \\
\hline Poor Knowledge $\quad(\leq 7$ score $)$ & $9(17.3)$ & $14(29.2)$ & 23 \\
\hline Good Knowledge $\quad(>8$ score $)$ & $43(82.7)$ & $34(70.8)$ & 77 \\
\hline Total & $52(100)$ & $48(100)$ & 100 \\
\hline
\end{tabular}




\subsection{Attitude of Diabetic Patients in This Study (Table 5 \& 6)}

Out of the total participants, $83 \%$ were aware that missing a diabetic medication dose will have a negative effect on their disease control and $89 \%$ reflected that it is necessary to keep in contact with their physician regularly. Even though $81 \%$ of the study participants followed controlled and planned diet, only $40 \%$ were involved in regular exercises.

Table 5. Correct responses to attitude items on diabetes among the study participants

\begin{tabular}{|c|c|c|c|}
\hline \multirow{2}{*}{ Attitude items } & \multicolumn{3}{|c|}{ Correct response } \\
\cline { 2 - 4 } & Male & Female & Overall \\
\hline Exercise regularly? (Y) & 30 & 10 & 40 \\
\hline $\begin{array}{c}\text { Following a controlled and } \\
\text { planned diet? (Y) }\end{array}$ & 40 & 41 & 81 \\
\hline $\begin{array}{c}\text { Missing doses of your diabetic } \\
\text { medication will have a } \\
\text { negative effect on your disease } \\
\text { control? (Y) }\end{array}$ & 45 & 38 & 83 \\
\hline $\begin{array}{c}\text { Blood sugar levels fall below } \\
\text { normal when you are taking } \\
\text { drugs? (Y) }\end{array}$ & 45 & 43 & 88 \\
\hline $\begin{array}{c}\text { Should keep in touch with your } \\
\text { physician? (Y) }\end{array}$ & 46 & 43 & 89 \\
\hline
\end{tabular}

Table 6. Level of Attitude towards diabetes among the study participants

\begin{tabular}{|c|c|c|c|}
\hline & $\begin{array}{c}\text { Male } \\
\text { N (\%) }\end{array}$ & $\begin{array}{c}\text { Female } \\
\text { N (\%) }\end{array}$ & $\begin{array}{c}\text { Overall } \\
\text { N (\%) }\end{array}$ \\
\hline $\begin{array}{c}\text { Positive attitude } \mathbf{(} \mathbf{3} \\
\text { score) }\end{array}$ & $48(92.3)$ & $40(83.3)$ & 88 \\
\hline $\begin{array}{c}\text { Negative attitude }(< \\
\text { 3 score) }\end{array}$ & $4(7.7)$ & $8(16.7)$ & 12 \\
\hline Total & 52 & 48 & 100 \\
\hline
\end{tabular}

Table 7. Diabetic practices of the study participants

\begin{tabular}{|c|c|c|c|}
\hline Variables & $\begin{array}{c}\text { Male } \\
(\mathrm{n}=52)\end{array}$ & $\begin{array}{c}\text { Female } \\
(n=48)\end{array}$ & $\begin{array}{l}\text { Overall } \\
(n=100)\end{array}$ \\
\hline $\begin{array}{l}\text { Regular visit to physician } \\
\qquad(\leq 1 \text { month })\end{array}$ & 41 & 33 & 74 \\
\hline $\begin{array}{c}\text { Blood sugars estimation } \\
(\leq 1 \text { month })\end{array}$ & 44 & 38 & 82 \\
\hline $\begin{array}{c}\text { Serum lipid estimation } \\
(\leq 6 \text { months })\end{array}$ & 37 & 27 & 64 \\
\hline Urine analysis ( $\leq 1$ month) & 39 & 35 & 74 \\
\hline $\begin{array}{l}\text { Blood pressure examination } \\
(\leq 1 \mathrm{month})\end{array}$ & 40 & 34 & 74 \\
\hline Eye examination ( $\leq 6$ months $)$ & 37 & 33 & 70 \\
\hline
\end{tabular}

\subsection{Practices of the Study Participants (Table $7 \& 8$ )}

Components like 'visiting the physician regularly, 'checking the blood glucose, lipid profile and urine analysis', examination of blood pressure and eye'; were included to assess the practices towards diabetes. An appreciable percentage of participants had regular visit to the physician (74\%). Additionally, the $82 \%$ and $64 \%$ of the study participants got their blood glucose and lipid analysis done within 1 and 6 months respectively. Further, $74 \%$ \& $70 \%$ of the participants also got their blood pressure and eye examination done within 1 and 6 months respectively. Among the total 100 study participants, $76 \%$ of them had good practices.

Table 8. Practices towards diabetes control and care among the study participants

\begin{tabular}{|c|c|c|c|}
\hline & $\begin{array}{c}\text { Male } \\
\text { N (\%) }\end{array}$ & $\begin{array}{c}\text { Female } \\
\mathbf{N}(\%)\end{array}$ & $\begin{array}{c}\text { Overall } \\
\text { N (\%) }\end{array}$ \\
\hline $\begin{array}{c}\text { Good Practice } \\
(>\mathbf{3} \text { score) }\end{array}$ & $41(78.8)$ & $35(72.9)$ & 76 \\
\hline $\begin{array}{c}\text { Poor Practice attitude } \\
\text { ( } \mathbf{3} \text { score) }\end{array}$ & $11(21.2)$ & $13(27.1)$ & 24 \\
\hline Total & $52(100)$ & $48(100)$ & 100 \\
\hline
\end{tabular}

\subsection{Factors Associated with Diabetic Knowledge among Study Participants (Table 9)}

The regression analysis showed increasing odds of good knowledge among females [(1.552 (0.559 - 4.311)] and also among participants with duration of diabetes of more than 5years $[1.090(0.278-4.264)]$. Further the analysis showed that the knowledge on diabetes was poor as participant's age advanced [OR: 0.281 , CI: $0.065-1.217 \&$ OR: $0.199(0.046-0.864)]$. Additionally, there was increased odds of good knowledge in participants with increase in educational level and was more with secondary education [OR: 3.964, CI: 0.692 - 22.686] (Table 9)

Table 9. Bivariant and Multivariant analysis of factors associated with Knowledge on Diabetics among diabetic patients.

\begin{tabular}{|c|c|c|c|}
\hline & \multicolumn{2}{|c|}{ Knowledge } & \multirow[t]{2}{*}{$\mathrm{OR}(\mathrm{CI})$} \\
\hline & Good & Poor & \\
\hline \multicolumn{4}{|c|}{ Gender } \\
\hline Male & 36 & 16 & Reference \\
\hline Female & 35 & 13 & $1.552(0.559-4.311)$ \\
\hline \multicolumn{4}{|c|}{ Age group (years) } \\
\hline $40-50$ & 27 & 3 & Reference \\
\hline $51-60$ & 19 & 10 & $0.281(0.065-1.217)$ \\
\hline$>61$ & 25 & 16 & $0.199(0.046-0.864)$ \\
\hline \multicolumn{4}{|c|}{ Educational status } \\
\hline Illiterate & 7 & 6 & Reference \\
\hline Primary & 12 & 11 & $0.699(0.156-3.123)$ \\
\hline Secondary & 23 & 3 & $3.964(0.692-22.686)$ \\
\hline Graduate & 29 & 9 & $1.897(0.453-7.938)$ \\
\hline \multicolumn{4}{|c|}{ Duration of diabetes (years) } \\
\hline$\leq 5$ & 60 & 25 & Reference \\
\hline$>5$ & 11 & 4 & $1.090(0.278-4.264)$ \\
\hline
\end{tabular}




\section{Discussion}

The present study reports the knowledge, attitude and practices towards diabetes control and also explores the determinants of diabetic knowledge among diabetic patients in the rural settings.

\subsection{Knowledge}

Diabetic patients with poor knowledge and poor glycemic control are susceptible for developing long term complications. Improving diabetes knowledge of diabetic people might allow achieving better glycemic control. The present study showed comparatively good knowledge (77\%) among diabetic patients, unlike most studies from developing countries which reported poor knowledge of diabetes among diabetic patient and public [10].This reasonable level of knowledge may be attributed to higher literacy rate $(87 \%)$ found among the participants of present study, even though this study didn't explore the source of knowledge acquisition on diabetes.

A very few studies have evaluated the impact of health education and awareness program on KAP and glycemic control in type 2 diabetes. They have shown that there is a reduction in glycate haemoglobin [3,11-12] and increase in mean KAP scores after imparting health education [13-15]. A study by Asmelesh D et al [16] concluded that more than half of the study subjects had good KAP towards glycemic control and showed that only occupational status and marital status were significantly associated with KAP towards glycemic status.

\subsection{Attitude}

The current study showed $88 \%$ of the participants with positive attitude towards diabetes, however it was very low $(40 \%)$ when considering the point of doing exercise regularly. A study conducted by Daniel Asmelash et al [16] reported $76.2 \%$ having good attitude towards glycemic control. The present study findings regarding attitude towards diabetes was higher than the studies undertaken in India [17] and other countries [18,19]. Even though the present study was conducted among the rural population, the positive attitude was high which may be due to better access to health education programs conducted by this teaching hospital. Further, awareness on health benefits of undertaking exercise regularly should be emphasized while providing health care services in the hospital and also during community health education campaign.

\subsection{Practices}

More than $3 / 4$ of the study population had good practices towards diabetes. About $82 \%$ of the subjects were getting their blood glucose checked regularly, however the study didn't explore regarding self-monitoring of glucose. This result is in accordance with the study done by Bruce $\mathrm{P}$ among diabetic patients attending tertiary care hospital at
Kulasekheram [2], but study by Sangra et al [10] and Upadhyaya et al [20] reported lower level of practices towards diabetes. Study done among the general population also has shown that around 30\% have regular screening for diabetes with annual blood glucose measurements [21]. Asmelash D et al [16] reported that factors like occupational status, educational status and marital status of the participants were significantly associated with practices towards glycemic status.

Adequate knowledge, attitude and practices are vital to enhance the self-care skills among diabetic patients. Previous studies have demonstrated that management of diabetic are strongly associated with adequate knowledge and well correlated with reduction in glycated haemoglobin $[3,22]$. Apart from medications, non-pharmacological interventions and adequate knowledge, attitude, and practices among diabetic patients become paramount importance in diabetes management. Health education is essential in resource poor primary care settings wherein diabetes pose great financial burden and calls for urgent participation of clinicians and health care workers to inform and motivate diabetic patients and to propagate healthy lifestyle practices vital for achieving glycemic control.

\subsection{Limitation of the Study}

The present study is a single centric study with a small sample size, hence results may not be generalized to the population.

\section{Conclusions}

The present study provides a snapshot of the current state of knowledge, attitude and practices related to diabetes among diabetic patients. Majority of the participants had awareness and knowledge about the diseases, missing a diabetic medication and its complications, and also, about the lifestyle modifications like consuming balance diet, medication, reducing weight, avoiding alcohol and smoking. However, there is a scope for improvement in the areas such as inclusion of regular exercise, regular lipid profile analysis and eye examination.

\section{Acknowledgements}

The authors would like to thank all the study subjects for their valuable time and responses provided and, we would like to acknowledge the support provided by the management in conducting this study.

\section{Conflict of Interest}

NIL 


\section{Financial Support}

NIL

\section{REFERENCES}

[1] World Health Organisation fact sheets Diabetes, "World Health Organisation," Available at: https://www.who.int/ne ws-room/fact-sheets/detail/diabetes.accessed on 21-06-19

[2] Bruce P, "Knowledge attitude and practice about diabetes among patients with diabetes attending medicine OPD of tertiary care hospital at Kulasekharam,"Int J Community Med Public Health, Vol.5,no.10,pp.4254-4257,2018, DOI:

http://dx.doi.org/10.18203/2394-6040.ijcmph20183824.

[3] Sumit Pal Singh Chawla , Sarabjot Kaur, Aman Bharti , Ravinder Garg, Manjeet Kaur , Divya Soin , Amrita Ghosh , Ranabir Pal, "Impact of health education on knowledge, attitude, practices and glycemic control in type 2 diabetes mellitus," J Family Med Prim Care, Vol.8, no.1,pp.261-268, 2019, doi: 10.4103/jfmpc.jfmpc_228_18.

[4] Ranabir Pal, Shrayan Pal, Ankur Barua, MK Ghosh, "Health education intervention on diabetes in Sikkim," Indian J Endocrinol Metab, Vol.14, no.1, pp.3 - 7, 2010, https://www.ijem.in/text.asp?2010/14/1/3/75070.

[5] Saurabh RamBihariLal Shrivastava, $\boldsymbol{\otimes}$ Prateek Saurabh Shrivastava, and Jegadeesh Ramasamy, "Role of self-care in management of diabetes mellitus," J Diabetes Metab Disord,Vol.12,pp.14, 2013; doi: 10.1186/2251-6581-12-14.

[6] Diana Sherifali , Lori D. Berard, Enza Gucciardi, Barbara MacDonald, Gail MacNeill, "Self-Management Education and Support," Can J Diabetes, Vol.42, pp.S36-S41,2018, https://doi.org/10.1016/j.jcjd.2017.10.006

[7] Shu Hui Ng, Kheng Hooi Chan, Zi Yang Lian, Yee Hooi Chuah, Aishath Noora Waseem, Amudha Kadirvelu, "Reality vs Illusion: Knowledge, Attitude and Practice among Diabetic Patients," International Journal of Collaborative Research on Internal Medicine \& Public Health, Vol.4,no.5,pp.723-732,2012.

[8] AlShareef MS, AlWabel AA, AlKhathlan AM, AlKhazi AA, AlMaarik KA, AlGarni MA, "Glycemic Control in Diabetic Patients in Saudi Arabia: The Role of knowledge and Self Management - Across - Sectional Study," Global Journal of health Sciences,Vol.9,no.12,pp.25-31,2017, DOI:10.5539/gjhs.v9n12p25

[9] “American Diabetes Association," Report of the Expert committee on diagnosis and classification of Diabetes Mellitus,Diabetes Care,Vol.27,pp.5-10,2004.

[10] Dr. Sonika Sangra, Dr. Nida Nowreen, Dr Sunil Sachdev, "Knowledge, Attitude and Practice about type 2 Diabetes Mellitus in an adult population attending a Primary Health Centre in rural Jammu," IOSR Journal of Dental and Medical Sciences, Vol.15, no.4, pp.54-57, 2016, DOI: 10.9790/0853-1504135457

[11] Marwa M. Ahmed, Hanaa M. El Degwy, Mayssa I. Ali, Nashwa H. Hegazy, "The effect of educational intervention on knowledge, attitude and glycemic control in patients with type 2 diabetes mellitus," Int J Community Med Public Health, Vol.2, pp.302-307, 2015, DOI: http://dx.doi.org/10. 18203/2394-6040.ijcmph20150487.

[12] Sheikh Mohammed Shariful Islam, \ Louis W Niessen, Jochen Seissler, Uta Ferrari, Tuhin Biswas, Anwar Islam, and Andreas Lechner, "Diabetes knowledge and glycemic control among patients with type 2 diabetes in Bangladesh," Springerplus, Vol.4, pp.284, 2015, doi: 10.1186/s40064-01 5-1103-7.

[13] Javedh Shareef, Jennifer Fernandes, Laxminarayana Samaga, Mahalingeshwara Bhat, "Effect of pharmacist led educational interventions on disease knowledge and glycemic control in patients with diabetes mellitus in a university hospital," Curr Res Diabetes Obes, Vol.1, no.2, pp.555-559, 2016, DOI: 10.19080/CRDOJ.2016.01.555559.

[14] Z Ghazanfari, F Ghofranipour, SS Tavafian, F Ahmadi, A Rajab, "Lifestyle Education and Diabetes Mellitus Type 2: A Non- Randomized Control Trial," Iran J Public Health,Vol.36,no.2,pp.68-72, 2007.

[15] Dr Sunita Gupta,Dr Mohit Singla, Dr Neeraj Gupta, “A study of impact of patient education of diabetes on his knowledge, attitude and practices," J Med Sci Clin Res, Vol.5, no.11, pp.30264-9, 2017, https://dx.doi.org/10.1853 5/jmscr/v5il1.77.

[16] Daniel Asmelash, Netsanet Abdu, Samson Tefera,Habtamu Wondifraw Baynes, Cherie Derbew, "Knowledge, Attitude, and Practice towards Glycemic Control and Its Associated Factors among Diabetes Mellitus Patients," Journal of Diabetes Research, pp.1-9, 2019, https://doi.org/10.1155/20 19/2593684.

[17] Gunvanti B. Rathod, Sangita Rathod, Pragnesh Parmar, Ashish Parikh, "Study of knowledge, attitude and practice of general population of Waghodia towards diabetes mellitus," International Journal of Current Research and Review,Vol.6,no.1,pp.63-68,2016.

[18] R. Kant and V. Thapliyal, "Knowledge attitude and practice of type 2 diabetic patients in a tertiary care teaching hospital in India," Integrative Food, Nutrition and Metabolism, Vol.2, no.1, pp.131-135, 2015, DOI: 10.15761/IFNM.1000115.

[19] Maina William Kiberenge, Zachary Muriuki Ndegwa, Eva Wangechi Njenga, Eva Wangui Muchemi4,“Knowledge, attitude and practices related to diabetes among community members in four provinces in Kenya: a cross-sectional study," Pan African Medical Journal,Vol.7,no.2,2010, Published online 2010 Oct 6 .

[20] Dinesh K Upadhyay, Subish Palaian, P. Ravi Shankar, Pranaya Mishra, "Knowledge, attitude and practice about diabetes among diabetes patients in Western Nepal," Rawal Med J,Vol.33,no.1,pp.8-11,2008.

[21] H M M Herath, N P Weerasinghe, H Dias ,T P Weerarathna, "Knowledge, attitude and practice related to diabetes mellitus among the general public in Galle district in Southern Sri Lanka: a pilot study," BMC Public Health, Vol.17, no.1, pp.535, 2017, DOI 10.1186/s12889-017-4459 -5 .

[22] S. Palaian, L.D. Acharya, P.G.M. Rao, P.R. Shankar, N.M. Nair, N.P. Nair, "Knowledge, attitude, and practice outcomes: Evaluating the impact of counselling in 
